\title{
PROLEGÓMENOS A UMA FENOMENOLOGIA \\ DO SENTIDO DA VIDA HUMANA \\ NOS ENSAIOS TARDIOS DE JAN PATOČKA
}

\author{
Ivan Chvatik \\ Center for Advanced Research in Phenomenology \\ Charles University - Prag
}

Em Novembro de 2002, por incitamento do nosso colega Lester Embree, um congresso internacional comemorou, em Praga, o nonagésimo quinto aniversário do nascimento do filósofo checo Jan Patočka, congresso que levou à fundação da Organization of Phenomenological Organizations. Nessa ocasião, apresentei um artigo sobre a fenomenologia da história de Patočka, no qual tentei mostrar, entre outras coisas, que Patočka é um pensador do conflito. Uma das razões para isso foi a sua experiência de vida como intelectual do século XX - ou antes, como pensador e "homem de espírito" -, porque o século $\mathrm{XX}$ foi, acima de tudo, ự século dado a guerras e a violências totalitárias contra nações inteiras numa escala global. No entanto, uma outra causa foi a sua experiência filosófica. Os primeiros passos da sua carreira filosófica foram marcados pela sua estadia em Friburgo, no ano de 1933, onde, graças a uma bolsa da Fundação Humboldt, preparou a sua dissertação de licenciatura sob a direç̧ão de Edmund Husserl, já na altura professor jubilado, e ouviu as lições de Martin Heidegger, ao tempo reitor da Universidade. Como a ajuda de Eugen Fink, assistente de Husserl, Patočka ficou em condições de perceber a diferença - já totalmente desenvolvida nessa época - entre as abordagens da fenomenologia por parte de Husserl e de Heidegger. Daí em diante, Patočka haveria de lutar toda a sua vida por uma maior claridade neste conflito filosófico e por um meio para o resolver. Creio que se pode dizer, sem exagero, que foi este esforço que motivou toda a sua obra filosófica, conduzindo-o a resultados excepcionalmente importantes, que como tal permanecerão pelos tempos vindouros. 
Um estudo aprofundado da fenomenologia husserliana e heideggeriana levou Patočka à convicção de que os conflitos e as crises, tanto nas vidas dos indivíduos como na história, têm sempre a sua origem, de uma maneira ou de outra, no conflito presente nas profundezas do próprio Ser. O Ser é conflituoso no seu próprio núcleo, em e por si mesmo, e esta luta ocorre na esfera mais apropriada para a fenomenologia: no vir-à-aparição, no campo fenomenal. A aparição daquilo-que-é depende da nossa compreensão daquilo que provoca a aparição de todas as coisas existentes, por outras palavras, depende do modo como o próprio Ser aparece. Esta compreensão do Ser permanece, no entanto, usualmente encoberta no processo do aparecer, naquilo que nos aparece, isto é, na aparição do ser particular enquanto tal. Para Patočka, a estrutura histórica do fenómeno, na forma que o dá na fase tardia da segunda metade do século XX, é verdadeiramente dramática: "encobrimento é, aqui, não simples cortina ou sombra; é, antes, conflito e luta, presentes na fonte do aparecer enquanto tal. Conflito em que sentido? $\mathrm{Na}$ medida em que a vida, que é vida-na-claridade, se torna nas coisas clarificadas; a transcensão é ensombrada por aquilo-que-é-transcendido e, consequentemente, a vida é negada no próprio viver. Isto mostra-se, então, não apenas como perigo, mas como qualquer coisa mais: implica também a inumanidade, aspereza e crueldade da vida para com a vida" (PD III, 394). ${ }^{1}$

A afinidade com Heidegger é bastante clara; no entanto, Patočka vai mais longe. Em vez de avisar contra um simples "perigo" (Gefahr), fala de conflito; em vez de preparar para o advento da "graça do Ser" (Gunst des Seins) pela arte e pelo pensamento (PD III, 392), intenta, como seu objectivo, agir na história. Numa exposição feita num seminário, sumaria a história da Fenomenologia numa frase: "Da tentativa de Husserl para resolver a crise por meio do conhecimento até o esforço de Heidegger para a resolver por meio da arte, chegámos à questão de saber se não será necessário afrontar o perigo, em vez de simplesmente esperar; e, ao mesmo tempo, [...] se este perigo não deverá ser compreendido não apenas como véu, mas antes como um conflito que nos envia para o combate e nos consumirá também nesse combate" (PD III, 393). Não muito depois de ter pronunciado estas palavras, tornou-se um dos três porta-vozes iniciais do movimento dos direitos humanos Carta 77 e, em Março de 1977, o choque deste movimento com o poder político do estado totalitário havia de lhe custar a vida.

Já na sua dissertação pós-doutoral, O Mundo da Vida como Problema Filosófico (1936), Patočka projecta a sua investigação sobre o mundo da vida como uma pesquisa histórica - uma investigação com o propósito de, em conformidade com o programa fenomenológico de Husserl, "fornecer

${ }^{1}$ PD III = Jan Patocka, Péče o duši III, Praha 2002, edição checa das Obras Completas de Jan Patočka, vol. 3. 
uma orientação na pré-história ideal de uma ideia teorética". Vê já que a tarefa de "clarificar as estruturas do aparecer na sua originalidade" e de conseguir acesso à "vida humana concreta no mundo" requerem, primeiro que tudo, uma "meditação sobre a história humana", uma espécie de filosofia fenomenológica da história. Pode-se dizer que ele continuou a desenvolver este tópico durante toda a sua vida. Sem dúvida que o resultado mais bem conhecido são os Ensaios Heréticos sobre a Filosofia da História, um conjunto de estudos, redigidos em 1974-75, que sumariam o seu projecto de toda uma vida de uma forma muito sucinta. A estreita ligação entre o tema do aparecer e da fenomenalização, de um lado, e o da história, do outro, é enunciada logo no primeiro ensaio: "A abertura do mundo, em todas as suas formas, é sempre histórica, ela depende do aparecer dos fenómenos e da actividade das pessoas que os preservam e mantêm através da tradição. A abertura ocorre como um acontecimento na vida dos indivíduos; no entanto, graças à tradição, ela diz respeito a todo e qualquer um" (PD III, 24). Num esboço preliminar deste texto, acrescenta: "No entanto, permanece para ver se a historicidade é um fenómeno singular, um momento fenomenal, se bem que importante e mesmo fundamental, ou se não é, antes, o fenómeno que deve ser considerado como elemento fundante da história, algo que estabelece a história e sem o qual a história seria impensável. Nesse caso, não apenas o fenómeno seria per se histórico, mas a história seria necessariamente fenomenológica" (PD III, 453).

Compreendendo a história como história da fenomenalização, compreendendo a estrutura da fenomenalização como formação histórica do conflito no interior do Ser, Patočka chega não apenas a conceber a sua investigação histórico-filosófica como uma fenomenologia do sentido da vida humana, ou talvez como uma história da filosofia do sentido, mas também a apresentar explicitamente e a tentar responder à questão acerca do sentido da vida humana e/ou da história. Tem a história um sentido? - tal é o título do terceiro "ensaio herético". Visa a história uma finalidade? É possível discernir, em todas as suas sinuosidades e voltas enredadas, algum tipo de conteúdo unificador? Certamente que uma tal questão é formulada apenas por alguém que sente uma falta de sentido. A falta de sentido global tornou-se, desde há algum tempo, a situação do todo da humanidade. Desde Nietzsche, e mesmo antes, tem havido um nome para ela: niilismo.

Nos seus ensaios sobre a Filosofia da História, Patočka mostra, contudo, que a "experiência da perda do sentido" (PD III, 82) vai muito mais atrás no tempo, e que o "abalo do sentido" (82) marca o próprio início do que tem sido designado como a época histórica. Não é um subproduto acidental da história; o princípio da história enquanto tal é, antes, constituido pela descoberta da natureza problemática da condição humana no mundo. Segundo Patočka, a história começa quando entra em colapso a compreensibilidade do mundo mediada pelos mitos - a compreensibilidade do mundo incluindo 
"poderes sobrenaturais, o elemento demoníaco, deuses que estão acima do homem, o governam e dirigem" (PD III, 28). Num tal mundo pré-histórico, muita coisa - talvez tudo - é misteriosa, mas não há espaço para levantar questões, pois as "questões pressupõem a possibilidade de libertação, uma distância relativamente àquilo que somos já e àquilo em que nos encontramos" (PD III, 28). Para Patočka, a história começa com esta "libertação", no momento em que os humanos começam a fazer explicitamente perguntas que eram desnecessárias no mundo mítico.

O termo que devemos sublinhar aqui é explicitamente. De outro modo, poder-se-ia objectar que a distância tomada relativamente ao mundo circundante imediato, que o transcender existencial da nossa condição momentânea em direcção ao futuro e ao passado, em direcção ao ausente e à esfera da imaginação são já uma característica da humanidade enquanto tal, desde tempos muito mais antigos, e que este distanciamento é idêntico ao facto de que os humanos falam, comunicam e alcançam uma autocompreensão por meio da linguagem. No entanto, uma tal compreensão pode - e, conforme afirmado por Heidegger em Ser e Tempo, fá-lo à partida e com mais frequência - permanecer auto-evidente de um modo aproblemático, de tal forma que as respostas cheguem antes de se poder sequer levantar a questão. Deste ponto de vista, o mito é uma articulação do sentido que é, por assim dizer, sorvida no peito materno; é uma narrativa que fornece respostas para todas as questões possíveis mesmo antes de elas surgirem abertamente como questões reais. É como se esta completude de sentido viesse de fora, e Patočka chama-lhe, portanto, sentido aceite. Todavia, isto não significa dizer que a era mítica não conhece interrogações importantes, pelo contrário. No entanto, os homens encontram as respostas dentro da narrativa mítica e são, portanto, conduzidos pela tradição enquanto questão respondida. Para Patočka, o questionamento explícito ocorre quando um indivíduo particular, para sua terrífica surpresa, dá corpo a uma interrogação para a qual a narrativa mítica não consegue dar uma resposta pronta, tal como tinha sido regra até então; isto força o indivíduo a tornar-se explicitamente consciente da estranheza da situação, a formular uma questão, a articular o seu espanto como seu próprio espanto e a mantê-lo enquanto tal, isto é, não, por exemplo, como temor dos poderes demoníacos, os quais as pessoas dos tempos míticos costumavam sempre esconjurar, sem qualquer efeito individualizador.

Assim que esta articulação ocorre e que a pessoa que a experienciou não a deixa apaziguar-se (apaziguar-se onde, de facto? No subconsciente? Ou talvez na narrativa mítica? Afinal, numa resposta feita depois, depois da formação dos mitos, para esta interrogação espantosa e excitante, e, resposta que é, depois disso, transmitida pelo mito como pronta a usar), assim que, em suma, a questão não é deixada cair mas aceite, tal como um duelista aceita o desafio, tornamo-nos numa pessoa diferente. Ao aceitarmos a nossa 
própria questão como um desafio que nos é lançado de fora, o distanciamento acima referido com relação ao mundo exterior, mundo que sempre esteve em jogo na linguagem, atinge a visibilidade plena. A luz que torna a distância visível provém da questão enquanto tal, mas a coisa mais essencial que vemos nela é que não temos resposta: o desafio foi lançado por um opositor obscuro com o qual não será fácil combater. No entanto, quem aceita o desafio é livre e está determinado a proteger a sua liberdade.

Isto é, em poucas palavras, a noção de Patočka da "libertação do mito", que se situa entre o colapso do sentido aceite e o início de uma procura explícita de sentido que não é já forçada a partir do exterior, mas antes encontrada livremente enquanto resposta para o nosso próprio questionar: um sentido acerca do qual podemos explicitamente assumir uma responsabilidade pessoal.

Para Patočka, os primeiros passos no caminho em direcção à realização deste programa podem ser encontrados nos Gregos antigos e nas suas cidades-estado independentes, nas quais foram fundadas as primeiras escolas de Filosofia e o questionar explícito ficou conectado com pessoas particulares conhecidas pelo seu nome. Patočka fala das origens comuns da Política e da Filosofia. Os cidadãos livres desses estados, tendo combatido pela sua liberdade e tendo-a estabelecido na luta, descobriram então os meios políticos para a manter, na base do mútuo reconhecimento entre partes rivais. Não querendo já basear as suas visões do certo e do errado, ou as suas decisões em situações problemáticas, nos receituários míticos, os cidadãos desejaram tomar do saber genuíno a sua base firme, tomar decisões fundamentadas.

Tal como Patočka a vê, a conexão mútua entre Política e Filosofia levou à construção de vários grandes sistemas metafísicos. Patočka menciona Platão, Demócrito, Aristóteles. Supunha-se que o conhecimento último da ordem do Universo tornaria possível a ordem nos assuntos humanos. No entanto, está aqui o ponto de fricção: "Assim, a Filosofia, enquanto Metafisica, deixa cair o mistério que causou a subversão de onde a própria Filosofia proveio - assim o mistério supera o mistério sob a forma da enigmática pluralidade dos conceitos metafísicos, sob a forma da pluralidade de intuições fundamentalmente diferentes acerca da natureza daquilo-que-é enquanto tal" (PD III, 73). Esta pluralidade, juntamente com as circunstâncias históricas do período helenístico, gera o cepticismo, ao demonstrar que a Filosofia, baseada na ordem do Universo, é "incapaz de conceder aos humanos um sentido da vida mais elevado, completamente positivo", um sentido despido de "todo e qualquer carácter misterioso trazido pelo despedaçamento do modesto modo como o mito fazia originalmente sentido" (PD III, 73).

É aqui que entra a Cristandade. São Paulo intitula "loucura" a sabedoria dos antigos filósofos, que se esforçaram por fundamentar o sentido nos seus conceitos metafísicos; ele oferece a todos um acesso directo ao sentido fornecido por um Deus transcendente. No entanto, ao rejeitar a supressão filo- 
sófica da problematicidade, o Cristianismo recusa a solução, mas não a questão. Pois o Deus cristão não aparece como qualquer coisa óbvia; não se trata de retornar simplesmente até a condição mítica. Deus requer fé explícita e, em virtude dela, Ele é uma resposta nova a uma antiga demanda. $\mathrm{O}$ Deus cristão fornece uma resposta apenas para os que desejam ouvi-la, para aqueles que Nele confiam e acreditam (PD III, 345/346).

$\mathrm{A}$ resposta cristã à problematicidade obteve um sucesso imenso. Confiança em Deus, combinada, em última instância, com elementos de metafísica antiga, deu nascença à civilização europeia moderna. O Cristianismo deu origem a uma racionalidade científica nova que, pelo seu lado, fez surgir a ciência natural matemática moderna, encorajando, ao mesmo tempo, o desenvolvimento da Teologia racional. "O homem moderno experimentou como uma nova vivacidade a esperança de que, no que concerne às verdades básicas da fé cristã, aos preambula fidei, agora libertos de todas as adjunções irracionais, o novo método racional forneceria uma prova válida de uma vez por todas, a priori, com uma certeza matemática" (3S, 55). Esta esperança também deu sentido à nova investigação científica, cujo objecto era, ao fim ao cabo, a Natureza enquanto criada por Deus. Ciência matemática e Teologia racional estavam intimamente conectadas no projecto de alcançar, com certeza apodíctica, um conhecimento da Natureza qua criatura de Deus. Os esforços metafísicos dos teólogos atingiram um ponto alto nas demonstrações racionais da própria existência de Deus. ${ }^{1}$

Esta viragem racionalista na evolução da Teologia estava destinada, porém, a tornar cada vez mais claro que a tarefa que ela se tinha dado a si própria a envolvia em antinomias racionalmente insolúveis. Ao tentar provar artigos de fé com a mesma força lógica e matemática que estava sendo atingida na investigação científica, a razão humana foi levada a perceber o carácter desesperado dos seus próprios esforços. Immanuel Kant formulou, por fim, este estado de coisas de um modo explícito e rigoroso. O propósito da sua filosofia "crítica" - ou seja, "discernente" - era o de libertar a Razão de tarefas que excedem as suas capacidades, de modo a permitir-lhe devotar todos os seus poderes à investigação científica no campo comensurável com as suas faculdades cognitivas. A Metafísica, tal como Kant a viu, deveria tentar demonstrar esta comensurabilidade. A escrupulosa honestidade intelectual com que ele se entregou à prossecução deste objectivo assegurou-lhe um papel-chave na história da Filosofia. Para lá de ter lançado os fundamentos da Gnosiologia moderna, tal como o sublinharam os neo-kantianos, fez também progressos decisivos (tal como o mostrou Heidegger) no campo

$1 \mathrm{Na}$ Introdução do seu estudo, Patočka refere de modo aprovativo Dieter Henrich, Der ontologische Gottesbeweis (Tübingen, 1960), com a sua análise detalhada do significado da Teologia racional para o desenvolvimento da ciência moderna. 
da Ontologia fundamental, influenciando, assim, toda a tradição filosófica subsequente até os nossos dias.

No seu último ensaio (KMFN, Samizdat 1977, agora em 3S, Praha 1991, 53-119), Patočka tentou, nas suas próprias palavras, "uma história da filosofia do sentido da vida humana desde $\operatorname{Kant}(3 \mathrm{~S}, 109)$. Isto foi feito primariamente com um propósito de estabelecer, em conclusão, uma revisão destas tentativas, sumariando, ao mesmo tempo, os seus próprios pontos de vista sobre o tema, que já eram de importância crucial nas considerações sobre a Filosofia da História, desenvolvidas nos Ensaios Heréticos. Ele estava, decerto, ciente de que a questão do sentido, assim definida, não poderia ser exaurida num curto ensaio. Por isso, afirma no final: "o nosso conspecto serviu apenas como prolegómenos históricos para esta questão e para os fenómenos pertinentes" (3S, 116). Infelizmente, Patočka não teve oportunidade para continuar desenvolvendo as suas ideias; teremos de nos avir com o esboço que está disponível. Tentarei, aqui, baseando-me na análise histórica de Patočka, apresentar o seu ponto de vista pessoal, tal como o entendo, e avaliar a questão da sua plausibilidade.

No início do seu ensaio, Patočka observa que, "frequentemente, não somos capazes de apreciar completamente o significado imenso da morte da Teologia racional, tal como foi trazida por Kant, tanto para a Filosofia como para a vida" (3S, 54). Quando a investigação científica foi liberada, largamente por Kant, dos últimos resquícios dos laços que outrora prenderam a ciência à Teologia, ela tornou-se numa esfera em que o conhecimento não pode descobrir nada mais do que processos mecânicos governados por uma inexorável causalidade. A nova ciência racional ficava órfã. Ela tornou-se numa "doutrina exclusivamente materialista da Natureza, enquanto desprovida de qualquer sentido" (3S, 54). Não mais uma e a mesma maneira de ver poderá garantir a liberdade da vontade, a alma imaterial e imortal, a existência e veracidade de Deus juntamente com a possibilidade de adquirir conhecimento do mundo criado da Natureza. Depois de Kant, não podemos mais olhar a Natureza como um livro escrito por Deus para nos dizer alguma coisa, ou seja, alguma coisa para além do que nela em todo caso vemos, a saber, que as suas letras estão ligadas por leis mecânicas inexoráveis. Torna-se claro que o livro da Natureza não contém, de facto, letras que se combinem em símbolos de qualquer coisa para além dela; não é um texto, muito menos um livro sobre Deus e os seus atributos: Imortalidade, Liberdade, Deus - estas coisas não podem ser encontradas na ciência natural.

O "significado imenso" de Kant, para citar Patočka, reside em ter provado este facto, sabido desde há muito, de um modo racional, irrefutável. O que fora há muito uma causa de apreensão e de ansiedade foi agora dotado de uma prova a priori. A ansiedade cedeu o lugar ao terror, que nos tem cativos ainda hoje, tal como é atestado, em minha opinião, pela própria tentativa de Patočka de desenvolver uma fenomenologia da significatividade, 
bem como por toda a sua Filosofia da História. Um outro sinal da crucial relevância destes problemas poderá ser encontrado - tanto entre os defenso-. res como entre os adversários - nos debates hodiernos sobre o "pós-modernismo", onde eles são ou ignorados ou tratados de um modo que impede a compreensão genuína.

Kant, primeiro que todos os outros, não podia abster-se de considerar a condição da Razão, a qual ele tinha posto a descoberto de um modo tão fundamental. Crente no seu racionalismo e no seu sentido para construir sistemas científicos, desenvolveu uma tentativa imponente para salvar a fé, ligando-a à esfera da Ética. Não é a fé no Deus Todo-Poderoso que exige obediência incondicional aos seus mandamentos. Pelo contrário: nós próprios estamos habilitados, por meio da nossa própria razão, a captar os mandamentos de Deus como rectos e justos, ou seja, como mandados pela nossa própria razão, porquanto somos aquilo que somos - seres racionais. No entanto, esta autonomia racional, tal como é expressa pelo imperativo categórico, é totalmente formal, abstracta e insensível, por assim dizer, dada a pureza do seu carácter racional, no qual as circunstâncias empíricas da nossa própria vida não têm qualquer papel. É incondicional em e por si mesma; e a vontade moral que segue o seu imperativo pode, enquanto vontade livre, realizar as suas acções morais no mundo empírico em todas as circunstâncias. Neste sentido, é inteiramente autónoma, auto-suficiente, nada mais sendo requerido para a sua consumação. Usando um termo não kantiano, poder-se-ia dizer que uma tal acção é significativa em si mesma, por outras palavras, que ela é sentido, e sentido absoluto: nenhuma necessidade há de olhar em torno e de registar, por exemplo, o impacto das nossas acções em nós próprios e na nossa envolvência. Tal actividade desconsidera precisamente aquilo em que é consumada, ou seja, a sua inserção numa série temporal empírica. Contudo, deixando para trás o carácter formal absoluto do imperativo e considerando de novo o mundo empírico, vemos que a acção moral jamais conseguirá atingir o summum bonum na esfera empírica da Natureza, a única em que ela é operativa.

Isto aponta para o facto, notável e perturbador, de que a acção moral, apesar da sua significatividade interna formal, pode ser destituída de sentido, do ponto de vista da consecução do seu objectivo. Confrontada com este facto - ligado à resistência que a realidade empírica oferece à actividade originando-se na liberdade, no que respeita a atingir o seu objectivo - e ciente de que a razão teórica é capaz de conhecimento nesta esfera, mas fundamentalmente incapaz de encontrar qualquer propósito último, e muito menos um propósito equivalente à consecução do summum bonum, a razão prática é forçada a postular Deus enquanto autor moral do mundo, como garantia de que este mundo, teoreticamente sem finalidade, realmente aspira, com a nossa participação, ao summum bonum. É, para além disso, compelida 
a postular uma alma imortal, de modo a que uma criatura moralmente activa, para lá dos limites da vida terrena, no ponto evanescente da eternidade, possa, pela participação neste summum bonum, alcançar, como recompensa pelas suas acções morais, a felicidade, que é um atributo necessário do summum bonum. Há um Deus moral e a alma é imortal: isto são, portanto, postulados da razão prática que requerem a crença, não descobertas da razão teórica, dedutíveis a partir de princípios. Eles articulam a exigência de uma harmonia que estabeleça uma ponte entre Natureza e Moralidade. Assim, se bem que não sejam descobertas racionais, são com certeza algo muito racional: a razão avança-os como algo que deve ser crido, de modo a reconciliar a incondicionalidade abstracta do imperativo moral com a existência corpórea e mortal do ser humano na sua integralidade. A Teologia moral é, assim, chamada a salvar a fé, reconciliando-a, ao mesmo tempo, com a razão - pois é a própria razão que requer a fé como algo necessário.

Se bem que as questões levantadas por Kant tenham sido pegadas por poetas da estatura de Goethe e Schiller, "o facto de que Hegel e Schelling, enquanto seguidores e oponentes de Kant, tenham retomado a Metafísica onto-teo-lógica", diz Patočka, "obscureceu grandemente a intuição, que começa em Kant, de que a metafísica da eternidade assumiu um novo estilo, um estilo guiado pelo sentido do mundo e da vida [...]". Patočka também observa que mesmo Husserl, no §4 da sua obra Crise das Ciências Europeias, falhou na plena apreciação das razões da crise que acometeu o entusiasmo iluminista na racionalidade universal, dado que "o leitor [da obra de Husserl] é necessariamente levado a crer que a causa do cepticismo [final] reside na permuta alternada e na contradição mútua dos vários sistemas [filosóficos]; no entanto, o cepticismo derivou não das diferenças, mas antes da ruína da base partilhada por todos os sistemas, ou seja, a demonstração racional da existência de Deus e, primariamente, a prova cartesiana, baseada no conceito de ens necessarium. Assim, o modo como a realidade foi despida de sentido no desenvolvimento do pensamento moderno é largamente diferente da imagem oferecida por Husserl; pois a alternativa husserliana entre naturalismo objectivista e transcendentalismo subjectivista - a seus olhos, o eixo da luta pelo sentido daquilo-que-é ao longo da Modernidade negligencia totalmente a problemática metafísica predominante que, de facto, preenche séculos inteiros, ao passo que a alternativa citada por Husserl entra em cena apenas aquando do seu colapso, ou seja, a partir de Kant. Isto causa uma distorção do papel de Kant, bem como de Descartes, no transcendentalismo moderno" (3S, 57).

Patočka compreende a tentativa racionalista de Kant para salvar a fé como um projecto implícito de uma metafísica do sentido da vida humana no interior do sentido global do Universo: "nenhum esforço humano é possível sem o sentido; [...] e, por outro lado, sem um sentido absoluto e total, colapsa todo e qualquer caucionamento [particular] de sentido" (3S, 60). Só 
o esforço consciencioso de Kant para assegurar que o bem sucedido projecto matemático-mecânico acerca da Natureza, que se torna significativo apenas pelos objectivos humanos relativos, encontra o seu fundamento absoluto num Deus transcendente faz surgir, na sua plena força, a questão do sentido do mundo e da vida. Até então, não tinha sido necessário. Contudo, isto também significa que a solução de Kant de um tal problema, talhado metafisicamente, não criou raiz. O que connosco ficou até os nossos dias é a sua articulação metafísica, com a sua exigência de que todo e qualquer projectar "relativo" de sentido, nas situações particulares da vida humana, encontre necessariamente uma base absoluta de suporte.

Nesta viagem de Patočka através da história da fenomenologia da significatividade, a paragem seguinte é Dostoyevsky. ${ }^{1}$ Patočka mostra como a solução de Kant para o problema do sentido acaba por ser desafiada: "Se o propósito do mundo e da vida consiste em ser encerrado no momento da harmonia última, tal como ela é perseguida por um esforço infinito para a perfeição moral, ele pressupõe um reconhecimento da desarmonia e do mal enquanto factos" (3S, 62). Do argumento de Ivan Karamazov segue-se que a aceitação de postulados morais não traz consigo qualquer necessidade absoluta; pelo contrário, depende da nossa intenção de agir em geral e da nossa expectativa da felicidade como recompensa. A partir do momento em que optamos por um tal sentido, o mal foi reconhecido, e pode-se mesmo afirmar que "isto é o preço a ser pago pela significatividade moral do mundo. Se deve haver qualquer coisa como mérito moral, deve haver também sofrimento e injustiça [...]. No entanto, será necessário que o mundo seja moralmente significativo?" (3S, 65) Patočka sublinha esta questão e mostra que o argumento de Dostoyevsky contra a significatividade moral "corre paralelamente ao argumento de Kant contra a Teologia racional. A refutação kantiana da onto-teo-logia está baseada na impossibilidade de assegurar qualquer conteúdo para o conceito de um ser necessário, e, da mesma maneira, a refutação, por parte de Ivan, da Teologia moral está baseada na impossibilidade de provar que o propósito moral do Universo é apodicticamente necessário" (3S, 66). Ivan Karamazov não rejeita a crença em Deus, mas antes o Deus dos postulados morais. Contudo, dado que ele pega no modo como o problema do sentido foi articulado pela metafísica da moralidade, para ele só há duas possibilidades em aberto: "ou há algum outro sentido, um sentido que ainda não podemos compreender, ou não há pura e simplesmente qualquer sentido [...] e [...] tudo é permitido" $(3 \mathrm{~S}, 68)$ - deveríamos agora dizer; tudo serve. Ao nível do fundamental, toda a obra de Dostoyevsky é consa-

1 Aqui, Patočka cita J. E. Golosovker - Dostojevskij i Kant, Moscovo, 1963. Ele encontra uma discussão conceptualmente incisiva da Teologia moral de Kant em Os Irmãos Karamazov, Parte II, Livro 5, Capítulo "Rebelião". 
grada ao drama da escolha entre estas duas alternativas. Patočka oferece uma detalhada análise do "homem do subsolo", de Dostoyevsky, como um céptico guinando de uma para a outra: esta figura faz recordar o "público anónimo" (Manselbst, das Man) de Heidegger, com a diferença, porém, que o "homem do subsolo" está ciente da sua decadência niilista e, se bem que sofrendo imensamente por sua causa, se acha incapaz de lhe escapar. A pequena história $O$ Sonho de uma Pessoa Risivel é considerado por Patočka como "a descrição mais abrangente do modo como superar este estado de subsolo" (3S, 71). Patočka observa nela um paralelismo com a noção heideggeriana de uma possível viragem das atitudes chãs básicas, através da angústia, enquanto experiência da nulidade de tudo aquilo-que-é, para a autêntica "metamorfose interna, capaz [...] de desvelar o fundo deste aparentemente óbvio curso de acontecimentos" (3S, 76). A metamorfose experimentada pela "pessoa risível" de Dostoyevsky, depois do seu suicídio em sonhos, como um encontro com o Sol, cuja luz ilumina todas as coisas e lhes concede vida, é interpretada por Patočka como uma revelação deste "fundo", como o descobrimento da diferença entre Ser e aquilo-que-é, como um reconhecimento do "milagre de que tudo é" $(3 \mathrm{~S}, 77)$. Este milagre do ser, manifesto quando todos os objectivos e propósitos humanos desaparecem como inúteis, "este milagre em virtude do qual estamos no meio [...] daquilo-que-é, é uma conjunção e uma abertura que pode, por isso, ser chamada "amor"”, (3S, 77), e este "amor tem o seu lugar não entre as coisas e os conteúdos mundanos, mas antes do lado do Ser imortal" (3S, 78).

Patočka tenta uma compreensão existencial da religião do amor, que Dostoyevsky lança contra a Teologia moral de Kant. "A harmonia, que o propósito moral do mundo empurra para uma distância infinita, está toda presente num súbito "aqui e agora"” (3S, 78). O mal não desapareceu do mundo e da vida, nem as pessoas se livraram do sofrimento e da morte, mas acabaram por conhecer a plenitude e estão reconciliadas. A recusa da continuação infinita traz consigo a recusa para saldar contas das ofensas, uma negação da vingança e, acima de tudo, a decisão de tomar sobre nós próprios a culpa de todos - um elemento visto por Patočka como paralelo à heideggeriana "vontade de consciência", de Ser e Tempo. O mundo não é desembaraçado da tragédia e do sem sentido, mas isto são, agora, coisas relativas. A própria morte torna-se significativa: o encontro com a nossa finitude torna possível que nos abramos para a fonte de sentido do "não-ser". No entanto, o sentido não se tornará manifesto como "recompensa pelos méritos, como paga e correcção dos erros. O sentido é qualquer coisa a que nos devemos entregar e devotar individualmente" (3S, 86).

Não será necessário dizer que Patočka não pretende apresentar a posição do próprio Dostoyevsky. Pelo contrário, ele afirma explicitamente: "Dostoyevsky descobriu, assim, um continente de sentido ainda desconhecido, ao passo que ele próprio crê ter apenas encontrado um novo caminho 
para chegar a terras conhecidas [...] A Teologia cristã fala de amor, e assim o faz Dostoyevsky [...], mas estarão ambos a falar da mesma coisa?" $(3 \mathrm{~S}, 86)$

Na parte seguinte deste ensaio (3S, 87-99), Patočka trata brevemente de T. G. Masaryk, um dos fundadores da Checoslováquia independente e seu primeiro presidente, em 1918, mas também um amigo de Husserl e um aluno de Brentano. Na sua primeira obra importante, Suicidio como Fenómeno Social de Massas da Civilização Moderna (1 $1^{\text {a }}$ edição de 1881), Masaryk propõe a ideia de uma adscrição das tendências suicidas modernas essencialmente ao "subjectivismo" moderno e à perda da crença religiosa. Patočka é um crítico acérrimo da abordagem positivista e sociológica de Masaryk à Filosofia da Religião e aos temas da significatividade que estivemos aqui a discutir; ele vê nisto a fonte da má leitura, por parte de Masaryk, tanto de Kant como de Dostoyevsky.

Não menos importante é a tomada de posição crítica de Patočka em relação a Nietzsche, aqui apresentado como um profeta do niilismo, que vê a crise da humanidade moderna no facto de que a interpretação metafísica do mundo e da vida, desde Platão até o Cristianismo de hoje, "tenta projectar para lá deste mundo o seu desejo de caucionamento do sentido para a realidade, [...] consignar todo e qualquer valor [...] a um mundo "verdadeiro", "ideal"” (3S, 101). O Cristianismo, porém, devido ao seu respeito pela verdade como um destes valores absolutos, revelou ele próprio a falsidade desta visão do mundo e, por aí, surgiu a terreiro como a fonte real de todo o niilismo. Para Patočka, Nietzsche é o defensor do "antropomorfismo, estabelecido como um princípio metafísico" $(3 \mathrm{~S}, 102)$. Tendo superado todo e qualquer "para lá" do mundo, o homem prevalece também sobre o niilismo por meio de uma nova positividade almejando a uma impiedosa subjugação do Planeta. "O mundo será conquistado por uma animalidade criativa, mas bestial e dura" (3S, 103). Patočka, tal como Heidegger, fala aqui de um "subjectivismo carnal e terreno" $(3 \mathrm{~S}, 106){ }^{1}$

Patočka parece falhar completamente ao tentar enfrentar a ideia nietzscheniana do "eterno retorno do mesmo". Patočka esforça-se por concebê-la meramente como uma "refutação da primeira tese de Kant e, consequentemente, da doutrina da antinomia da razão pura em geral" $(3 \mathrm{~S}, 104){ }^{2} \mathrm{O}$ "eterno retorno", de acordo com Patočka, "conduz a uma noção do Universo como um jogo combinatório, que não admite nem a liberdade nem a própria compreensão da existência do mundo enquanto vontade" (3S, 105), com o

${ }^{1}$ Deve observar-se que a attitude de Patočka em relação à filosofia de Nietzsche pouco difere do ponto de vista que toma gradualmente forma nas conferências de Heidegger em 1936$-1946$.

2 C. Kant, Crítica da Razão Pura, A 426 / B 454. 
resultado de que Nietzsche "resolve o problema da significatividade de um modo que bane radicalmente o sentido no seu todo" (3S, 105). Surpreendentemente, Patočka termina esta crítica de Nietzsche como se segue: "O chamamento de Nietzsche ecoa na nossa compreensão crescente do carácter terreno não como um mero facto, mas antes como um compromisso, como algo que devemos fitar com os olhos bem abertos, como algo a ser considerado não como indiferente, mas como uma realização paradoxalmente ligada a um sentido mais profundo" (3S, 107).

Patočka olha, assim, o niilismo hodierno como "a convicção auto-evidente de que só existe sentido relativo, ou seja, relacionado com a vida humana. Dado que a vida humana. enquanto tal é [...] necessariamente precária, toda e qualquer significatividade pode ser abalada, e se não foi ainda questionada, sê-lo-á em breve" (3S, 108). O diagnóstico de Nietzsche permanece válido. A humanidade contemporânea não tem expectativas de eterna felicidade ou da punição infligida à alma imortal por um criador todo-poderoso. Os postulados de Kant nada mais são do que palavras vazias e, no processo, o próprio imperativo moral perdeu também a sua incondicionalidade. $\mathrm{O}$ homem é deixado a si próprio. Para não ver esta perda de um sentido abrangente, ele recorre a uma multiplicidade crescentemente variada de sentidos relativos, à impessoalidade anónima do divertissement de Pascal.

Patočka concorda com Nietzsche no que respeita ao diagnóstico. Ele reenvia a causa principal da crise niilista até Kant, o qual, como já mencionámos, pensou a sua Teologia moral sem ter em conta o conceito de significatividade. A sua doutrina dos postulados está inteiramente baseada na noção de fim ou de propósito: o "summum bomum", sendo um fim, é algo a ser atingido, uma realidade vindoura, mesmo que seja num futuro infinito. Ele é qualquer-coisa-que-é, algo ôntico. Na nossa discussã̃o de Dostoyevsky, já tomámos devida nota da tentativa, por parte de Patočka, de chegar a uma compreensão nova da significatividade, mostrando como o sentido abrangente apareceu ao abalado "homem do subsolo" como um fenómeno ontológico, fonte da existência de todas as coisas, se bem que ele próprio não possa ser dito existente. Em plano de fundo das considerações de Patočka sobre significatividade, podemos subentender a definição formulada por Heidegger em Ser e Tempo e citada por Patočka no seu ensaio terá a História um Sentido?: "o sentido é aquilo sob cuja base algo se torna compreensível" (PD III, 62). No entanto, "o sentido, enquanto estrutura formal-existencial de descobrimento, pertencente à compreensão", ${ }^{1}$ não é um ente particular (Seiendes). Será, portanto, impróprio "deduzir o sentido, com a auto-evidência de algo não problemático, do propósito e da intenção, porque, na nossa vida, os propósitos provêm de uma apreensão reflexiva e de uma fixação

C. M. Heidegger, Sein und Zeit, Tübingen, 1929, p. 151. 
daquilo que tem e que assegura o sentido" (3S, 116). Podemos talvez escapar à crise niilista deixando de entender a significatividade a partir dos propósitos, realizando uma "revisão da filosofia do sentido da vida humana no seu todo [...] desde Kant" (3S, 109).

Neste esforço, Patočka faz uso de motivos heideggerianos. Ele está plenamente consciente de que "o próprio Heidegger não levantou explicitamente a questão do sentido [...] em toda a sua amplitude, nem tratou o tema do sentido parcial e abrangente, relativo e absoluto" (3S, 115). Então - que propõe Patočka?

Primeiro ponto importante: o sentido não é qualquer coisa que o próprio homem assegure, como com os postulados kantianos da razão prática. Devemos encontrar a significatividade de um modo similar ao que foi descrito por Dostoyevsky na história de Zosima, o seu irmão Marcel, ou a "pessoa risível" depois do seu suicídio em sonhos. O sentido deve aparecer num pulo existencial, "para lá do limite das significatividades relativas à vida humana" (3S, 109). Esta viragem é descrita por Martin Heidegger na conferência intitulada Que é a Metafisica?: pela experiência do "nada", descobrimos a diferença ontológica, a distinção entre Ser (Sein) e qualquer ente particular (Seiendes), somos postos perante a positividade do facto do Ser, somos fascinados pela sua imensidão. Esta positividade é a fonte actual de toda a significatividade: "Todo o significado, todo o valor, todos os fins estão derradeiramente fundados na compreensão deste "é", "há", "é dado", "está aberto", "está presente", enunciados antes de tudo aquilo que diz respeito à efervescência da nossa própria vida" (S3, 110). "Significatividade é uma categoria ontológica que originalmente, no seu ser primordial, não tem nana que ver com valores humanos, preocupações e propósitos [...] Significatividade, enquanto fonte de toda a compreensão, é a $U r$-diferença entre Ser e qualquer ente particular" (3S, 113).

O sentido abrangente está, numa palavra, não-relacionado com o homem, e isto leva-nos a outra importante característica: "ele está condicionado por qualquer coisa que não é nem humana nem um aspecto ou propriedade do homem, porquanto ele não tem existência, não é um ente particular" (3S, 115). Ele não pode, pois, seguir o caminho de todos os fins e valores metafísicos, susceptível de ser refutado: pelo contrário, é "um sentido que, posto a descoberto por colapso, não colapsa ele próprio, mas, não-real e não-ser, permanece intacto na catástrofe que faz soçobrar o sentido de todas as coisas reais" (3S, 111). Nesta perspectiva, pode-se chamar-lhe "absoluto" (cf. PD III, 81).

Esta absolutez significa, obviamente, que não há uma última palavra metafísica. Como observámos logo no início, o sentido abrangente é revelado de um modo histórico. Subir acima do sentido relativo à vida humana é um esforço que temos de realizar sempre de novo. Para Patočka, o caucionamento do sentido "com o objectivo da vida apenas para a vida" marca "o ponto-zero do esforço histórico humano" (PD III, 456). Em todos os 
momentos, a sua questionação desenrola-se no quadro da dicotomia entre o surgimento e a queda, sendo sempre o "ponto-zero" equivalente à queda. $\mathrm{O}$ seu oposto é o movimento que aspira à libertação da queda: surgimento ou élan. Este élan é transportado por um esforço em direcção à "vida na verdade" (PD III, 456) - não sendo a verdade tomada nem como adequação, nem como qualquer coisa mística, mas antes como qualquer coisa próxima da verdade do Ser heideggeriana, o desdobramento historicamente modelado da esfera do aberto, na qual aquilo-que-é é levado à aparição, a esfera em que se realiza a fenomenalização. Para Patočka, esforçar-se pela vida na verdade é, sempre de novo, o esforço para nos sentirmos em casa nesta esfera do aberto, para a volver em fenómeno, uma e outra vez, para pôr a descoberto o modo como aquilo-que-é nos aparece. A razão para esta repetição e constante re-assunção é que a finitude fundamental do ser humano na verdade, do Ser enquanto tal - se aplica mesmo aqui, na esfera do fenómeno ontológico. Mesmo aqui, algo essencial é retido naquilo que é posto a descoberto: "Um tal descobrimento, se bem que liberando aquilo-que-vem-à-superfície, oculta algo igualmente essencial, e seria mesmo impensável sem este ocultação, inerente ao fenómeno" (PD III, 455). Mesmo a respeito de fenómenos ontológicos, a estrutura do aparecer implica a ocultação, para lá do fenómeno aparecente, daquilo que o faz aparecer, requerendo, pois, um esforço continuamente renovado depois da desocultação. A estrutura do aparecer - ou, como diz Patočka, "o fenómeno" - é por esta razão "o elemento fundamental da história", o brotamento que mantém o curso da história. A história é história dos nossos esforços para descobrir fenómenos ontológicos, à medida que saem do encobrimento de modos sempre novos. Descobrir fenómenos ontológicos, estando dirigidos, ao mesmo tempo, para o facto de que eles próprios nos aprecem e para o modo como o fazem - tal é a forma como tentamos compreender o processo de desocultação, perceber onde estamos relativamente a ele.

Ao aprofundar os fenómenos ontológicos, o nosso objectivo era apenas o de compreender o modo como aquilo-que-é nos aparece, ou seja, compreender fenómenos ônticos. Queríamos perceber por que entes particulares, num certo tempo, nos aparecem exactamente do modo como o fazem e não de outra forma, como aconteceu em outro tempo, ou como desejamos que eles o venham a fazer. Aqui, a ideia de Patočka difere notoriamente da de Heidegger. Enquanto Heidegger aconselha a que esperemos, em devotada meditação sobre as formas históricas do fenómeno ontológico, e que nos preparemos para o momento em que o Ser tenha misericórdia de nós e se mostre de outro modo que na desditosa constelação do Gestell, Patočka quer ligar directamente a desocultação dos fenómenos ontológicos com a acção histórica: se, como é o caso, estivermos em condições de compreender os fenómenos ontológicos, se estivermos em condições de compreender por que os fenómenos ontológicos (entes particulares, das Seiende) nos aparecem 
do modo como o fazem, então poderemos e, na verdade, deveremos agir de acordo com o que pomos a descoberto - se quisermos evitar a queda cobarde ou o monótono viver pela própria vida.

Apesar da sua "absolutez", o sentido que nos é caucionado na desocultação do fenómeno ontológico permanece problemático. Problemático, por um lado, porque jamais poderemos ter a certeza de que nos abrimos à revelação da "verdade do Ser" de tal maneira que o Ser se possa manifestar do modo que deseja; não podemos jamais estar seguros de que realmente o deixámos ser e mostrar-se a si próprio sem juntar ao seu aparecer adjunções "subjectivas" que o adulteram, não podemos jamais estar seguros de que "ou estamos a ser capazes de compreender o seu carácter inconspícuo como a misteriosa presença de imensas riquezas, ou estamos apenas a retirar dele alguma dádiva, alguma mensagem que permitiria que nos instalássemos como senhores da nossa envolvência" (3S, 114). Problemático, por outro lado, porque, como vimos, este sentido absoluto "aparece como fruto da escuridão, propagando-se inexoravelmente nos próprios fundos do Universo" (PD III, 81, nota a).

A história é, então, um processo de revelação do sentido, se bem que um processo "de natureza problemática, completamente diferente de uma via segura em que se pudesse caminhar sem esforço" (PD III, 455). É uma via em que cada um deve sustentar uma constante perturbação da percepção ingénua da significatividade" (PD III, 69) e "abrir os seus olhos para a obscuridade, para a problematicidade, para as contradições" (PD III, 81, nota a), tomando consciência que "se é presenteado com uma dádiva inabalável, incomensurável com tudo o que é relativo (3S, 117). Patočka diz: "O homem enfrenta uma tarefa imensa - reclamar a significatividade. do Universo não para si mesmo e para seu benefício, mas antes compreender-se a si próprio como uma criatura que existe na base e por mor do sentido, vivendo em ordem a que um mundo significativo possa ser, desgastando-se para que o sentido, cujo fundamento "está" para além de tudo aquilo-que-é, possa vir morar e multiplicar-se naquilo-que-é” (3S, 117).

De tudo o que disse até aqui, é claro que Patočka, ao procurar o sentido, está principalmente preocupado com o seu carácter global ou, como ele próprio diz por vezes de um modo quase apologético, com a sua "absolutez". O ponto de partida de Patočka é uma intuição que ele compartilha com Wolfgang Weischedel: " "todo sentido parcial e condicional depende do sentido incondicional e total, que tem fenomenalmente precedência sobre ele" (PD III, 65). "Todo sentido particular remete para o sentido abrangente, todo sentido relativo remete para o absoluto" (PD III, 66/67). Daí a interrogação: será o sentido absoluto pensável depois de Kant e de Nietzsche? 
À primeira vista, esta pergunta poderia parecer afirmativamente respondida com a identificação do sentido abrangente com a esfera ontológica. Foi, portanto, produzida prova de um sentido abrangente e, num certo sentido, absoluto da vida e da história. A noção da significatividade abrangente como problemática demonstrou, para além disso, uma compreensão da historicidade deste sentido e a necessidade da acção humana na história. No entanto, creio que há aqui uma dificuldade relacionada com o ponto nodal de toda esta concepção, ou seja, com a própria procura de um sentido abrangente e absoluto. Se identificamos o sentido abrangente com a fonte de luz em que todas as coisas aparecem, se proclamamos que ele é uno com "a verdade primordial, pressuposta por todas as várias verdades e inverdades, falsidades e erros a que a vida está exposta" (3S, 111), não damos conta de que, do mesmo modo que esta "verdade primordial" é a fonte das verdades e inverdades, falsidades e erros, ela será também a fonte tanto do sentido como do sem-sentido.

Claro que o sentido ou o sem-sentido de que falamos aqui são relativos, referidos à situação em que o homem age. Na Teologia moral de Kant, bem como na actividade histórica baseada no "sentido inabalável, incomensurável com todas as coisas relativas" $(3 \mathrm{~S}, 117)$, aquele que age deve tomar uma decisão baseada no "entendimento" (Urteilskraft), que é necessariamente hermenêutico no seu carácter. Contudo, enquanto, na Teologia moral de Kant, o imperativo categórico tinha um direito de veto e, portanto, excedia a situação hermenêutica da acção de um modo absoluto, na nossa presente situação nós não temos à nossa disposição nada desse tipo. A "verdade primordial", o modo como - e, mais importante, o facto de que - a nossa situação se abre para nós é, sem dúvida, constitutiva da nossa compreensão dela própria, mas não pode ajudar-nos a evitar o sem-sentido de uma situação particular em que nos encontremos. De facto, a problematicidade, explicitamente proclamada, do "sentido abrangente" não pertence à esfera ontológica, tão pouco como o conflito do Ser, se bem que a problematicidade seja uma característica necessária da significatividade enquanto tal: o sentido não é sentido se não for passível de ser abalado, se não for direccional, orientado, em todos os casos, em relação a uma certa forma de sem-sentido. ${ }^{1}$

Patočka assumiu que o "sentido abrangente" estava isento desta direccionalidade. Enquanto não-ser, é indestrutível. Ele é explicitamente oposto à precária finitude da existência humana. $\mathrm{Na}$ verdade, ele é dito aparecer no próprio estado existencial básico da angústia, na qual estamos perante a nossa "possibilidade última extrema, impossível de antecipar e de partilhar, a possibilidade da não-existência" (3S, 111). Como se a descoberta de um "sentido abrangente" pudesse ser tirada à nascença, abolir ou dissimular o sem-sentido da morte - permanecendo, apesar de tudo, a morte aquilo de

Cf. P. Kouba, Nietzsche. Filosoficka interpretace. Prague, 1995, p. 141. 
onde a criatura finita e mortal retira todo o seu peso. Pôr o "sentido abrangente" acima do sentido ou sem-sentido relativo da nossa situação leva, derradeiramente, tal como na onto-teo-logia metafísica, a um nivelamento da diferença situacional entre (relativo) sentido e sem-sentido. Somos, de certo modo, chamados a escolher entre "sentido" abrangente e absoluto (ontológico, não-objectivo e inabalável), por um lado, e as formas puramente ônticas e mutáveis do sentido e sem-sentido relativos.

Não acaba isto por ocultar de novo a precariedade do sem-sentido potencial, ou seja, a característica existencial fundamental sem a qual a estrutura temporal do nosso ser - dividido entre um passado que não pode ser desfeito, assegurado do sentido irrefutável do nosso presente e um futuro que, com toda a sua incerteza, torna possível a projecção de um sentido diferente pelo qual o presente pode ser sacrificado - não seria possível? Seguir os passos de Patočka e pensar o conflito no Ser significaria, então, pensar a acção situada - com o sentido sempre em causa, para ser perdido ou preservado - não como "meramente relativo", mas antes na sua gravidade dramática, cuja consequência é verdadeiramente ontológica.

\section{ABSTRACT}

Jan Patočka (1907-1977), Czech philosopher of world importance, wrote his habilitation script with Edmund Husserl in Freiburg, where he also became acquainted with the work of Martin Heidegger. In his own work, Patocka tried to resolve the philosophical conflict between their various concepts of phenomenology. The attempt to add a historical dimension to the notion of Lebenswelt and to the concept of phenomenon as such led him ultimately to formulate a phenomenological philosophy of history. In his last essay, which is the main subject of my lecture, Patočka sketches out a "history of the philosophy of the meaning of human life, beginning with Kant" and sets forth his own concept of the meaning of history, influenced by Heideggerian motifs. I present a concise interpretation of his idea and take a critical position towards it. 